\title{
Investigation of Burnout among Instructors Working at ESOGU Preparatory School
}

\author{
Dr. Ümit Özkanal \\ Foreign Languages Department \\ Eskişehir Osmangazi Üniversitesi Yabancı Diller Bölümü \\ Çamlık Kampüsü 26010 Eskişehir- Turkey \\ Tel: 90-222-237-4400/134Ｆax: 90-222-237-9913Ｅ-mail: ozkanal@gmail.com
}

\author{
Nadire Arıkan \\ Foreign Languages Department \\ Eskişehir Osmangazi Üniversitesi Yabancı Diller Bölümü \\ Çamlık Kampüsü 26010 Eskişehir- Turkey \\ Tel: 90-222-237-4400/118Ｆax: 90-222-237-9913Ｅ-mail: nadirearikan@gmail.com
}

\begin{abstract}
Burnout is an issue to be taken seriously in the workplaces where human interaction is salient and very important. The aim of the research is to investigate burnout among the instructors working at ESOGU preparatory school and find out what factors affect their levels of burnout. 28 instructors working in this institution participated in the study. The results of the study showed that the only significant contributor of burnout among the instructors is their perceived level of stress at the workplace. Except for that one, demographic characteristics, educational background and other work-related factors proved to have low or no significant effect on instructors' burnout levels.
\end{abstract}

Keywords: Burnout, Preparatory school instructors, Teacher stress

\section{Introduction}

The welfare and health of the employees in an institution are the most important elements in terms of the effectiveness of the institution. When the employees feel relaxed and happy, they work better and do their jobs in a motivated way, which is quite important for the function of the institution involved. The case is also the same for people who work for educational institutions, especially for teachers or instructors working for colleges or universities. However, the contrast, feeling unhappy and not being willing to work, is also possible and even more common when many teachers or instructors (the term "instructor" is mainly used in this study) feel depressed in their workplaces due to some reasons, like stress, which affect their motivation and will for work negatively.

\section{Teacher Stress and Burnout}

Stress is a biological term which refers to the consequences of the failure of a human or animal to respond appropriately to emotional or physical threats to the organism, whether actual or imagined. It is the autonomic response to environmental stimulus. It includes a state of alarm and adrenaline production, short-term resistance as a coping mechanism, and exhaustion. Common stress symptoms include irritability, muscular tension, inability to concentrate and a variety of physical reactions, such as headaches and elevated heart rate (Selye, 1956).

Job stress, on the other hand, (means) refers to the job related nervousness and anxiety, which affects human's physical and/or emotional health (Netemeyer, Maxham and Pulig, 2005). It is believed that work overload and role stress are the two major stressors (Miller, Zook, and Ellis, 1989; Starnaman and Miller, 1992). While work overload refers to the heavy work-load demands, role stress means the form of role ambiguity and role conflict (Dillon and Tanner, 1995; Miller at al., 1989). It is known that teacher stress has become a growing hazard of the teaching profession (Pettegrew and Wolf, 1982). Stress among teachers is said to have been recognized as a widespread problem in different educational settings (Boyle, Borg, Falzon and Baglioni, 1995; Kyriacou, 2001; Dick and Wagner, 2001). Recent studies show that stress has become a global concern since in these studies teachers regarded teaching as quite stressful (Borg, 1990). In educational settings, the main causes of stress can be aligned as students' misbehaviors, discipline problems, students' poor motivation for school, heavy workload, time pressure, conflicting relationships among staff, administration and others (Dunham, 1992; Travers and Cooper, 1996). While some of these stressors are effective for some instructors, it is not the case for others and instructors react differently to these stress-makers (Milstein and Farkas, 
1988). Researchers state that some instructors may develop varied psychological symptoms ranging from frustration, anxiety to emotional exhaustion besides psychosomatic and depressive symptoms (Dunham, 1992; Farber, 1984a,b;Kyriacou and Pratt, 1985; Kyriacou and Sutcliffe, 1978b; Schonfeld, 1992; Seidman and Zager, 1991). As it is pointed out by some researchers, teacher stress may cause a range of consequences ranging from physical, psychological, behavioral to emotional problems like fatigue, illness, absenteeism, poor job performances, alcohol and drug abuse, reduced job satisfaction, and burnout (Ray and Miller, 1991).

The term burnout is used when people are not happy about what they have been doing and when they feel depressed about their jobs and when they have the symptoms mentioned above. It is known that many have been affected by so called burnout effect which means the state of physical and emotional depletion resulting from conditions of work (Freudenberger, 1974). According to Maslach (2003), burnout is the physical, mental and emotional exhaustion resulting from chronic job attrition. In another definition by Maslach, Jackson, and Leiter (1996), burnout is a syndrome of exhaustion, cynicism, and reduced professional efficacy. In this definition, exhaustion refers to feelings of strain, particularly chronic fatigue mainly resulting from overtaxing work. Cynicism refers to an indifferent or a distant attitude towards work mainly and the people with whom one works, losing one's interest in work and feeling for work has lost its meaning. Lastly, lack of professional efficacy refers to reduced feelings of competence, successful achievement, and accomplishment both in one's job and the organization (Hakanen, Bakker and Schaufeli, 2006).

Burnout appears in three dimensions: emotional exhaustion, depersonalization and reduced personal accomplishment (Maslach, 1982). The first, emotional exhaustion is depicted by feelings of frustration, anger, depression and dissatisfaction. The second dimension, depersonalization means a dehumanized and impersonal view of others and treating them like ordinary things rather than people. The last dimension, reduced personal accomplishment refers to a loss of self-efficacy on the job and the tendency to evaluate oneself negatively (Maslach, 1982, 2003).

It is pointed out that burnout problem among teachers has negative consequences for both teachers and those with whom they work, including emotional, attitudinal, and physical exhaustion. Individual consequences of burnout may include physiological and psychosocial problems (Grayson and Alvarez, 2007). It is also stressed that burnout can lead to psychopathology and deterioration in social and family relations (Cano-Garcia, Padilla-Munoz and Carrasco-Ortiz, 2005).

The risk of burnout is said to be greatly increased by teachers having perceptions of unmet or unrealistic goals and a lack of development of professional accomplishment (Evers, Tomic, and Brouwers, 2004). As teachers have these perceptions, they also start suffering from burnout in different dimensions.

In triggering burnout reactions among teachers, the role of context and school environment is stated to be effective by either facilitating or inhibiting an individual's emotional and attitudinal characteristics (Cano- Garcia, et al., 2005). The work of Bronfenbrenner (1974) who places importance on the broader social, institutional and cultural contexts of people-environment relations is one of the early researches about the topic.

There is still need for new researches to be conducted in this area to explore the concept of burnout among university instructors in Turkey. This study was carried out at the English preparatory school of Eskisehir Osmangazi University to investigate if burnout is effective among the instructors. The school has about 600 students from different faculties, most of whom are from Engineering Faculty and 28 instructors are in the department. The program started in 1996 and it has never been investigated in terms of institutional attitude and will for work since then. The aim of this study is to investigate the burnout levels of the instructors and the factors triggering burnout in EFL instructors who work in a preparatory school.

\section{Research Questions}

1) What is the level of emotional exhaustion, depersonalization and reduced personal accomplishment of the instructors working at preparatory school of ESOGU?

2) Are there any differences among burnout levels in terms of instructors' personal factors working at preparatory school of ESOGU?

3) Are there any differences among burnout levels in terms of instructors' educational backgrounds working at preparatory school of ESOGU?

4) Are there any differences between among burnout levels in terms of work related factors for instructors working at preparatory school of ESOGU?

\section{Methodology}

\subsection{Participants}

A total of $28 \mathrm{EFL}$ instructors at Eskişehir Osmangazi University participated in this study. The participants were chosen on voluntary basis. 
When personal factors were analyzed, it was seen that $67.8 \%$ of the participants were female while $32.1 \%$ of them were male participants. In terms of age, $32.1 \%$ of the participants were between 25 and 30; $46.4 \%$ were between 31 and 35 ; $10.7 \%$ were between $36-40$; and $10.7 \%$ were 40 and above. With regard to marital status, the participants reported that $39.2 \%$ of them were single; $57.1 \%$ of them were married and $3.5 \%$ of them marked "others" option. With respect to the number of children, $60.1 \%$ of the instructors did not have any children; $25 \%$ of them had only one children; and $14.2 \%$ of them had two children.

When educational factors were considered, $71.4 \%$ of the participants had BA diplomas while $28.3 \%$ of them had MA diplomas. In terms of years of experience, $17.8 \%, 46.4 \%, 25 \%$, and $10.7 \%$ had 2 to 4,5 to 10,11 to 15 , and 16 to 20 years of experience, respectively. Weekly work load was $15-18$ hours for $7.1 \%$ of the participants; $19-22$ hours for $10.7 \%$ of them; $23-26$ hours for $67.8 \%$ of them and 27 hours and above for $14.2 \%$ of them. All the participants were instructors; however, there were those who were responsible for some certain tasks. $53.5 \%$ of the participants were only instructors, while $3.1 \%$ were both instructors and administrative staff; $17.9 \%$ were both instructors and coordinators; and $25 \%$ of them were instructors working in an office in the institution. When the instructors were asked about their stress level at that time, $14.2 \%$ reported that they felt a little stress; 42.8 reported average stress level; $25 \%$ stated high; and 17.8 reported very high stress level.

\subsection{Instruments}

The Turkish version of Maslach Burnout Index (MBI) for educators adapted by Girgin (1995) was used in the current study. It includes 22 items which are designed to reflect three dimensions of burnout, namely Emotional Exhaustion, Depersonalization and Reduced Personal Accomplishment. The participants were required to mark these items on 7-point Likert scale ranging from "Never" to "Always".

\subsection{Procedure}

After getting necessary consents from administration and the participants, the questionnaire (in Appendix A) including 3 parts, comprising demographic data about the participants, basic information about their job-related tasks and Turkish version of Maslach Burnout Inventory for teachers was delivered to all the instructors working in Foreign Languages Department at Eskişehir Osmangazi University. 28 complete questionnaires were gathered back and all were used in this study. The results gained from the inventory were scored using MBI scoring key given in Kulavuz's (2006) thesis.

Data collected from the above-mentioned instruments were analyzed using Microsoft Excel Program 2007. After scoring burnout inventory, correlations between burnout levels and personal factors, educational background and work related factors (Eker and Anbar, 2008) as well as instructors' perceived stress level were calculated to answer the research questions.

\section{Findings and discussion}

The current study was designed to investigate the burnout levels of Turkish EFL instructors working in different levels, namely elementary, pre-intermediate, and intermediate levels, at preparatory school of ESOGU. The data gained from the questionnaires was analyzed quantitatively. The burnout levels of the teachers were analyzed and the relationship between the burnout levels and personal, school related factors and the instructors' perceived stress level were examined. The results gained have been presented in the article according to the research questions investigated in the study.

a. What is the level of emotional exhaustion, depersonalization and reduced personal accomplishment of the instructors working at preparatory schools at university level?

The results indicated that 5 out of 28 instructors suffered from burnout in all three burnout dimensions, namely Emotional Exhaustion, Depersonalization, and Lack of Personal Accomplishment. 3 of the instructors were moderate while 2 of them were low in all the dimensions.

5 of the participants had high burnout level in two dimensions, Emotional Exhaustion and Lack of Personal Accomplishment. 2 of the participants had high burnout level in Emotional exhaustion and these participants had low or moderate burnout levels in other two dimensions. 2 of the participants had high burnout level in Lack of Personal Accomplishment and they had low or moderate burnout levels in other two dimensions.

In summary, in almost all levels, instructors had burnout in significant levels, which suggests that all the instructors participated in the study were affected by burnout.

Insert Table 1 Here

The personal factors investigated in this study are gender, age, marital status, and the number of children the participants had. The results of the correlation analysis indicated that there is low correlation between the burnout levels and gender and marital status. Moreover, there is no correlation found between burnout levels and age and the number of children. In brief, when the table examined, demographic features proved to be ineffective in burnout of the 
instructors, which is inconsistent with the previous studies (Heus and Diekstra, 1999, Byrne, 1991; Byrne, 1999; Anderson and Iwanicki, 1984; Schwab and Iwanicki, 1982; Maslach, Schaufeli\& Leiter, 2001).

Insert Table 2 Here

In terms of educational background, the results of correlation analysis showed that there is low and no correlation between Emotional Exhaustion and Depersonalization and Lack of Personal Accomplishment, respectively.

Insert Table 3 Here

Years of experience, weekly work load, position in the workplace and the perceived stress level are considered as the work related factors. In terms of experience, the results were not significant because correlations were low for depersonalization and there is no correlation for Emotional Exhaustion and Lack of Personal Accomplishment. When weekly workload was considered, there was negative moderate correlation for EE and D dimensions, which is inconsistent with the previous studies ((Freudenberger, 1974; Dunham, 1992; Travers and Cooper, 1996) whereas there was low correlation between burnout levels and LPA. The results related to position in the workplace also revealed similar results. There was high correlation between perceived stress level and EE; however, moderate correlation between burnout levels and D and LPA.

All in all, the findings gained in the present study are not congruent with the previous studies, which indicates that the participant instructos in this study haven't been affected negatively by the factors causing high level of burnout.

\section{Conclusion}

The present study was conducted to investigate burnout levels of the instructors and the factors of burnout affecting EFL instructors working at preparatory school of ESOGU. The results indicated that approximately 18 percent of the instructors had high burnout level and this percentage is insignificant. When the factors related to burnout were investigated, the results showed that the correlation between demographic characteristics, namely gender, age, marital status and number of children and burnout dimensions was low or nonexistent, which is inconsistent with the results of the previous studies (Byrne, 1999; Anderson and Iwanicki, 1984; Schwab and Iwanicki, 1982; Maslach, Schaufeli\& Leiter, 2001). According to the results, factors related to educational background proved to have no effect on teachers' burnout levels. The only significant result revealed that is related to work related factors is the relation between the Emotional Exhaustion level and perceived stress level, which is congruent with previous studies (Suzumura, Tachi, Takeynama, Ebara, Sakai, and Itani, 2007; Eker and Anbar, 2008).

The reason for insignificant levels of burnout among participants may be due to the relationship among the instructors, for example, collaboration among the instructors and between the instructors and the administration. Zhang and Zhu (2007) suggested in their studies that collaboration proves to have a soothing effect on the instructors and relieve teacher burnout. At the context of the present study, preparatory school, almost all the decisions are made with the participation of all instructors and administration and also it can be said that there is always a mutual understanding between the aforementioned parties. Therefore, it is possible to state that this collaboration may contribute to insignificant levels of burnout among these instructors despite being exposed to the factors mentioned as the main causes of burnout in the literature.

\section{References}

Anderson, M. B. \& E. F. Iwanicki. (1984). Teacher motivation and its relationship to burnout, Educational Administration Quarterly, 20, 94-132.

Borg, M.G. (1990). Occupational stress in British educational settings: A review, Educational Psychology 10, 103-126.

Boyle, G.J., Borg, M.G., Falzon, J.M. \& Baglioni, A.J. (1995). A structural model of the dimensions of teacher stress. British Journal of Educational Psychology, 65, 49-67.

Bronfenbrenner, U. (1974). Psychological costs of quality and equality in education. Paper presented at the conference on psychological factors on poverty, Medison, Wisconsin.

Byrne, B. M. (1991). Burnout: investigating the impact of background variables for elementary, intermediate, secondary, and university educators, Teaching and Teacher Education: An International Journal of Research 7, 197-209.

Byrne, B. M. (1999). 'The nomological network of teacher burnout: a literature review and empirically validated model', in R. Vandenberghe and A. M. Huberman (eds.), Understanding and Preventing Teacher Burnout Cambridge University Press, Cambridge, 15-37

Cano-Garcia, F. J. Padilla -Munoz, E. M. and Carrasco-Ortiz, M. A. (2005). Personality and Contextual variables in teacher burnout. Personality and Individual Differences, 38, 929-940.

Dick, R. van \& Wagner, U. (2001). Stress and strain in teaching: A structural equation approach. British Journal of Educational Psychology 71, 243-259. 
Dillon, J. F. \& Tanner, G. R. (1995). Dimensions of career burnout among educators. Journalism and Mass Communication Educator, 50, 4-13.

Dunham, J. (1992). Stress in teaching (2nd ed.), Routledge, London, UK.

Eker, M. \& Anbar, A. (2008). Work Related Factors That Affect Burnout among Accounting and Finance Academicians. İş, Güç: The Journal of Industrial Relations and Human Resources, 10.

Evers, W. J. G, Tomic, W. \& Brouwers, A. (2004). Burnout among teachers: Students' and teachers' perceptions compared. School Psychology International, 25, 131-148.

Farber, B.A. (1984a). Stress and burnout in suburban teachers, Journal of Educational Research 77, $325-337$.

Farber, B.A. (1984b) Teacher burnout: Assumptions, myths, and issues, Teachers College Record 86, 321-338.

Freudenberger, H. (1974) Staff burnout, Journal of Social Issues 30, 159-166.

Girgin, G. (1995). İlkokul Öğretmenlerinde Meslekten Tükenmişliğin Gelişimini Etkileyen Değişkenlerin Analizi ve Bir Model Önerisi, Doctoral dissertation, Dokuz Eylül University.

Grayson, J.L. \& Alvarez, H.K. (2007). School climate factors relating to teacher burnout: a mediator model, Teaching and Teacher Education 23, 1349-1363.

Hakanen, J.J., Bakker, A.B., \& Schaufeli, W.B. (2006). Burnout and work engagement among teachers. Journal of School Psychology, 43, 495-513.

Heus, P. De \& Diekstra, R. F.. W. In Vanderberghe, R. \& Huberman, A. M. (1999). (Eds.). Understanding and preventing teacher stress. A sourcebook of international research and practice. Cambridge Universite press

Kulavuz, D. (2006). Exploring Burnout and Participation in Professional Learning Activities among University Prep Turkish EFL Instructors. Doctoral Dissertation, Boğaziçi University.

Kyriacou, C. (2001). Teacher stress: Directions for future research, Educational Review 53, 27-35.

Kyriacou, C. \& Pratt, J. (1985)Teacher stress and psychosomatic symptoms, British Journal of Educational Psychology $55,61-64$.

Kyriacou, C. \& Sutcliffe, J. (1978b). Teacher stress: Prevalence, sources, and symptoms, British Journal of Educational Psychology 48, 159-167.

Maslach, C. (1982). Burnout: The cost of caring. Englewood Cliffs, NJ: Prentice-Hall.

Maslach, C., Jackson, S. E. \& Leiter, M. P. (1996). Maslach burnout inventory manual (3rd ed.). Palo Alto, CA: Consulting Psychologists Press.

Maslach, C. (2003). Job burnout: New directions in research and intervention. Current Directions in Psychological Science, 12, 189-192.

Maslach, C, Schaufeli W. B. \& Leiter, M. P. (2001) Annual Review of Psychology, 52, 397-422.

Miller, K., Zook, E. G., \& Ellis, B. H. (1989). Occupational differences in the influence of communication on stress and burnout in the workplace. Management Communication Quarterly, 3, 166-190.

Milstein, M.M. \& Farkas, J. (1988). The overstated case of educator stress, Journal of Educational Administration 26, 232-249.

Netemeyer, R. G., Maxham, J. G. \& Pullig, C. (2005). Conflicts in the work-family interface: Links to job stress, customer service, employee performance, and customer purchase intent. Journal of Marketing, 69, $130-143$.

Pettegrew, L. S. \& Wolf, G. E. (1982). Validating measures of teacher stress. American Educational Research Journal, 19, 373-396.

Ray, E. B. \& Miller, K. I. (1991). The influence of communication structure and social support on job stress and burnout. Management Communication Quarterly, 4, 506-527.

Schwab, R. L. \& Iwanicki, E. F.(1982). Who are our burned out teachers?, Educational Research Quarterly 7, 5-16.

Schonfeld, I.S. (1992). Assessing stress in teachers: Depressive symptoms scales and neutral self-reports of the work environment. In: J.C. Quick, L.R. Murphy and J.J. Hurrell Jr., Editors, Stress and well-being at work: Assessment and interventions for occupational mental health, American Psychological Association, Washington, DC, $270-285$.

Seidman, S.A. \& Zager, J. (1991). A study of coping behaviors and teacher burnout, Work and Stress 5, $205-216$.

Selye, H. (1956). The Stress of Life, New York: McGraw-Hill.

Starnaman, S. M. \& Miller, K. I. (1992). A test of a causal model of communication and burnout in the teaching profession. Communication Education, 41, 40-53. 
Suzumura, H., Tachi, N., Takeynama, H., Ebara, T., Sakai, Y., \& Itani, T. (2007). Work-related factors contributing to burnout in university hospital nurses. Nagoya Med. Journal, 49, 1-15.

Travers, C.J. \&Cooper, C.L. (1996). Teachers under pressure: Stress in the teaching profession. Routledge, London, UK.

Zhang, Q. \& Zhu, W. (2007). Teacher stress, Burnout, and social support in Chinese Secondary Education. Human Communication, 10, 4, 487-496

\section{Appendix A}

\section{Değerli Arkadaşlar,}

Bilimsel bir çalışma için Yabancı Diller Bölümü Hazırlık sınıflarında görevli öğretim elemanlarının tükenmişlik düzeyleri hakkında bir araştırma yapılmaktadır.

$\mathrm{Bu}$ anket formunda istenen bilgilerin amacı kesinlikle öğretim elemanını değerlendirmek olmayıp, genel olarak tükenmişlik kavramını daha iyi anlayabilmektir. Bunun için, sorulara içtenlikle cevap vermeniz çok önemlidir.

Çalışmada yer alan öğretim elemanlarının ismi kesinlikle gizli tutulacaktır. Toplanan bilgiler sadece bilimsel amaçlar için kullanılacaktır.

Bu çalışmaya yapacağınız değerli katkılar için şimdiden teşekkür ederiz.

Ümit Özkanal

Nadire Arıkan

Uygun seçeneği işaretleyiniz.

Bölüm I: Kişisel Bilgiler
A. Cinsiyetiniz: 1 . Kadin ( )
2. Erkek ( )
B. Yaşınız:
1. 25- 30 ( )
2. 31-35( )
3. 36-40 ( )
4. 40 üzeri ( )
C. Medeni durumunuz: 1. Bekar ( )
2. Evli ( ) 3. diğer ( )
D. Çocuk sayısı: 1 . Yok ( )
2. 1 tane ( )
3. 2 tane ( )
4. 3 ve üzeri ( )

Bölüm II: Mesleki Bilgiler

A. Eğitim durumunuz:

1. Lisans: Üniversite / Bölüm:

Y1l:

2. Yüksek Lisans: Üniversite / Bölüm: Y1l:

3. Doktora: Üniversite / Bölüm: Y1l:

B. Meslekte çalışma süreniz: 1. 2-4 yıl ( )

C. Haftalık ders yükünüz: 1. 12-14 saat ( ) 2. 5-10 yil ( ) 3. 11-15 y1l ( ) 4. 16- $20 \mathrm{y1l}(\mathrm{)}$

\section{23- 26 saat ( )}

2. 15- 18 saat ( )

3. 19- 22 saat ( )

D. Pozisyonunuz: 1. Öğretmen ( ) 2. İdareci ( )

3. Gurup sorumlusu ( )

4. Ofis sorumlusu ( )

E. Şu anki mesleğinizde stres düzeyiniz: 1. yok ( ) 2. az ( ) 3. ortalama ( )

$$
\text { 4. yüksek ( ) }
$$

5. çok yüksek ( )

6. aşırı ( ) 


\begin{tabular}{|c|c|c|c|c|c|c|c|c|}
\hline & & $\begin{array}{l}\text { Hiçbir } \\
\text { Zaman }\end{array}$ & $\begin{array}{c}\text { Cok } \\
\text { Nadiren }\end{array}$ & Nadiren & Bazen & Genellikle & Çok Sık & $\begin{array}{c}\text { Her } \\
\text { Zaman }\end{array}$ \\
\hline 1. & $\begin{array}{l}\text { İşimden duygusal olarak uzaklaştığımı } \\
\text { hissediyorum. }\end{array}$ & & & & & & & \\
\hline 2. & $\begin{array}{l}\text { İ̧̧ gününün sonunda kendimi bitkin } \\
\text { hissediyorum. }\end{array}$ & & & & & & & \\
\hline 3. & $\begin{array}{l}\text { Sabahları uyanıp diğer bir işgünü ile } \\
\text { karşılaşmak zorunda olduğumda kendimi } \\
\text { yorgun hissediyorum. }\end{array}$ & & & & & & & \\
\hline 4. & $\begin{array}{l}\text { Öğrencilerimin neler hissettiklerini kolayca } \\
\text { anlayabilirim. }\end{array}$ & & & & & & & \\
\hline 5. & $\begin{array}{l}\text { Bazı öğrencilerime kişiliği olmayan } \\
\text { nesnelermiş gibi davrandığımı hissediyorum. }\end{array}$ & & & & & & & \\
\hline 6. & $\begin{array}{l}\text { Bütün gün insanlarla çalıșmak benim için } \\
\text { gerçekten bir gerginliktir. }\end{array}$ & & & & & & & \\
\hline 7. & $\begin{array}{l}\text { Öğrencilerimin sorunları ile çok etkin bir } \\
\text { biçimde ilgilenirim. }\end{array}$ & & & & & & & \\
\hline 8. & İşimin beni tükettiğini hissediyorum. & & & & & & & \\
\hline 9. & $\begin{array}{l}\text { İşim nedeni ile diğer insanların yaşamlarını } \\
\text { olumlu yönde etkilediğimi hissediyorum. }\end{array}$ & & & & & & & \\
\hline 10. & $\begin{array}{l}\text { Bu mesleğe girdiğimden beri insanlara karşı } \\
\text { daha katı oldum. }\end{array}$ & & & & & & & \\
\hline 11. & $\begin{array}{l}\text { Bu mesleğin beni duygusal olarak } \\
\text { katılaştırmasından endișe duyuyorum. }\end{array}$ & & & & & & & \\
\hline 12. & Kendimi çok enerjik hissediyorum. & & & & & & & \\
\hline 13. & $\begin{array}{l}\text { İşimin beni hayal kırıklığına uğrattığııı } \\
\text { hissediyorum. }\end{array}$ & & & & & & & \\
\hline 14. & İşimde çok sıkı çalıştığımı hissediyorum. & & & & & & & \\
\hline 15. & Bazı öğrencilere ne olduğu umurumda değil. & & & & & & & \\
\hline 16. & $\begin{array}{l}\text { Doğrudan insanlarla çalışmak bende aşırı } \\
\text { gerginlik yapıyor }\end{array}$ & & & & & & & \\
\hline 17. & $\begin{array}{l}\text { Ögrencilerime rahat bir atmosferi kolayca } \\
\text { oluşturabilirim. }\end{array}$ & & & & & & & \\
\hline 18. & $\begin{array}{l}\text { Öğrencilerimle yakın olduğum bir çalışmadan } \\
\text { sonra kendimi neşeli hissederim. }\end{array}$ & & & & & & & \\
\hline 19. & Bu meslekte birçok değerli işler başardım. & & & & & & & \\
\hline 20. & Kendimi çaresiz hissediyorum. & & & & & & & \\
\hline 21. & $\begin{array}{l}\text { İ şimde duygusal sorunlarla soğukkanlılıkla } \\
\text { ilgilenirim. }\end{array}$ & & & & & & & \\
\hline 22. & $\begin{array}{l}\text { Öğrencilerimin bazı sorunlarından dolayı beni } \\
\text { suçladıklarıı hissediyorum. }\end{array}$ & & & & & & & \\
\hline
\end{tabular}

Table 1. Are there any differences between the burnout levels in terms of instructors' personal factors?

\begin{tabular}{|l|l|l|l|}
\hline & EE & D & LPA \\
\hline Gender & 0.101344 & 0.114877 & -0.23061 \\
\hline Age & -0.0103 & 0.067295 & -0.11488 \\
\hline Marital status & 0.230456 & 0.170336 & -0.26716 \\
\hline No. of children & -0.08337 & -0.08286 & -0.00306 \\
\hline
\end{tabular}

Table 2. Are there any differences between the burnout levels in terms of instructors' educational backgrounds?

\begin{tabular}{|l|l|l|l|}
\hline & EE & D & LPA \\
\hline Educational Background & 0.116578 & 0.045972 & 0.029677 \\
\hline
\end{tabular}

Table 3. Are there any differences between the burnout levels in terms of work related factors?

\begin{tabular}{|l|l|l|l|}
\hline & EE & D & LPA \\
\hline Years of Experience & 0.005671 & -0.10219 & -0.03451 \\
\hline Weekly work load & -0.36416 & -0.46132 & 0.242562 \\
\hline Position & 0.254649 & 0.329777 & -0.40105 \\
\hline Perceived stress level & 0.828568 & 0.467379 & -0.48795 \\
\hline
\end{tabular}

